\title{
THE TRIAL JUDGE AWARDS CUSTODY
}

\author{
CARI A. WEINMAN*
}

\section{INTRODUCTION}

The trend of human behavior presages an increasing responsibility upon the judges of our courts who have jurisdiction of divorce proceedings. In peacetime this trend will become more evident for after the war we must face a marriage problem of great magnitude. The functions of the judge must necessarily be attuned to meet this coming problem.

We speak of the court as an entity, commonly referred to as "a hall of justice." In their inherited procedure, courts follow our statutes and the interpretations thereof, the common law rules, and the precedents established in prior cases which have been considered and reported. In domestic relations cases, however, judicial determination does not follow the usual machinery of justice. The judge considers the legal concepts together with the social problems which are involved in each case.

In each divorce proceeding involving the ancillary issue of custody of children, perplexing social problems exist. Their application to the final judgment is a personal responsibility of the judge. There is no uniform approach to guide him. He naturally follows the dictates of his own conscience in assuming this responsibility. In this respect his decision will be affected by his own experience, his education, his family life, his character, his temperament, and his philosophical and religious background. There are no definite rules which a judge can follow in determining the best interests of children. The correct answers may depend upon his special social knowledge and experience. The attitude of the community and the opinions of his associates may have some effect upon his decision. His personal knowledge of the family involved may be a guide. The number of cases that he is called upon to determine, may seriously affect the proper allocation of time to the particular domestic relations problem involved. This is especially true in larger counties. When too many cases are assigned for hearing on one day, it is only natural that the first case will receive more attention than the last case of the day. One reacts more like a legal machine as the day progresses. Realizing how serious this can be, many courts withhold judgment until they have had sufficient opportunity to satisfy themselves that their decisions are just and equitable. This

A.B., I924, LL.B., 1926, University of Michigan. Member of the Ohio State Bar Association and American Judicature Society. Member of the Judicial Council of the Ohio State Bar Association. City Solicitor, Steubenville, Ohio, 1932-1936. Judge of the Court of Common Pleas of Jefferson County, Ohio since 1937. Vice-President, Common Pleas Judges' Association of Ohio 1944. Contributor to legal periodicals. 
factor of allocating proper time for the determination of all the issues involved is extremely important. When the docket is not too heavy the approach to this problem may well be more realistic. This is true in the smaller counties. Here the judge can take the time, if he wishes to make such an effort, to investigate and consider carefully the attendant social aspects of the case. Often the judges are too legalistic and unwilling to assume social responsibility. This social responsibility is infrequently taught in our legal institutions, law schools or in our law books. Many judges, however, appreciate its importance and assume their responsibility to society in this respect.

\section{The Question of Custody}

The judges of our courts, with statutory jurisdiction of divorce proceedings, have full authority to provide for the custody and support of the minor children of the marriage. The court not only has the power, but also the responsibility of looking after the welfare of the children involved. This duty may require more than a consideration of the evidence presented. The circumstances may require a special investigation instituted by the court to determine the true facts. ${ }^{1}$ Collusion does exist in divorce cases, although the law frowns upon it. Parties do manufacture evidence, which often calls for a separate investigation. Many judges institute such an investigation when they are not satisfied with the facts presented because they question the weight of the evidence or the veracity of the witnesses. Judges are aware that there is rarely one absolutely innocent party to a divorce action, and that the discovery of the true cause of failure of the marriage may be an important fact in regard to the future welfare of the children involved. Lawyers and witnesses may purposely exaggerate minor matters in divorce cases, and judges can sense this exaggeration in the reading of the petition and the hearing of the evidence. The complaints set forth in the petition usually have little relation to the true facts. These allegations are merely convenient statements set forth by the lawyer to explain adequately his grounds for divorce. Furthermore, judges know that parties hesitate to divulge the actual truth with respect to the cause of their marital troubles. Witnesses may be reluctant to testify. Private conferences are often necessary to gain the confidence of the parties and the proceedings are necessarily informal. We do find most trial courts, according to their right and duty, attempting to ascertain any and all the pertinent facts. They make any investigation of conditions which will be of assistance in reaching a proper solution of the custody problem. Technical rules of pleading and practice are of little importance, and therefore are not countenanced and do not have any controlling effect in the final determination. ${ }^{2}$

Our law of domestic relations grew out of the English common law doctrine that the state or its agent, the court, is the ultimate parent of all minors and as such requires its care and protection. This doctrine can be traced back to the feudal

1 Ohto Gen. Code Ann. (Page, 1938) \$11979.

${ }^{2}$ Williams v. Gwynes, 97 S. W. (2d) 988 (Tex. Civ. App. 1936). 
times in England, when the Crown assumed jurisdiction over the estates of minors for the benefit of the Crown. The common law doctrine that the Crown is parens patriae, father of his country, is but the medieval way of expressing what we mean today when we say that the state is guardian of our social interests. In recent years the judge in the exercise of his present powers has seen fit to use his broad equitable discretion with relation to this problem. This equitable jurisdiction over the person of infants is based upon parental duty. It is recognized that the jurisdiction is a delicate one and rests in the highest degree upon the enlightened discretion of the court. $^{3}$ This determination as to the custody of minor children constitutes a wellrecognized branch of equity jurisdiction. ${ }^{4}$ The tendency of our courts today is to consider more and more the rights of the children when they are in opposition to the legal rights of the parents. We thus find our statutory law changing with our social consciousness. The fundamental principle of the common law was that the father possessed the paramount right to the custody and control of his minor children. It was Blackstone who said: "A mother as such is entitled to no power but only to reverence and respect." It has been quite a struggle for the courts, even with the aid of the statutes, to avoid following this ancient doctrine. ${ }^{5}$ The American rule seems universal that the courts of justice may, in their sound discretion, and when the morals or safety or interests of the children strongly require it, withdraw their custody from the father and confer it upon the mother, or take the children from both parents and place the care and custody of them elsewhere. ${ }^{6} \mathrm{We}$ have departed from the old English common law rule which favors the paternal right of custody. Today the idea of equality of rights for men and women and the necessity of ministering to the needs of the minor children is stronger than the idea of paternal control.

The same tribunal which hears the divorce cause has power to select the parent or a third party to whom the children shall be entrusted. The court may also make provision for their support. The welfare of the child is the paramount consideration and this determination rests upon the judgment of the judge before whom the case is presented. The question as to the particular custody which will best subserve the welfare and interests of the child is one which rests very largely in the sound discretion of the trial court. Each case is determined according to its own circumstances. The rights to be regarded are those of the child, the parents, society and of any who may have performed obligations as parents.

When they have jurisdiction of the person, courts have authority to make temporary and permanent orders in regard to custody. Courts may also in their discretion make such orders and decrees for the care and custody of children while

\footnotetext{
${ }^{3}$ The statutes of the different states use different language in authorizing this discretion. For example, N. Y. DoM. REL. LAw \$70: "In all cases there shall be no prima facie right to the custody of the child in either parent, but the court shall determine solely what is for the best interest of the child and what will best promote its welfare and happiness and may award accordingly."

10 R. C. L. 245 (1920); 12 R. C. L. IIOI (1920); I7 AM. JUR. 512, \$674 (1938).

${ }^{8}$ See generally Annotation, 41 L. R. A. (N. S.) 565 (I93I).

- I Schouler, Domestic Relations (6th ed. 1895) 794 .
} 
the divorce proceedings are pending, as they may consider proper. In determining temporary orders, however, judges consider the length of time that is involved before the case it to be tried on its merits. They also keep in mind that a delay in this respect may save the family. Ordinarily the custody of children pending the trial of the suit is not changed, unless there appears to be an exceptional or unques-. tioned cause for so doing. ${ }^{7}$ The factors which judges consider in determining custody of children are generally the same in whatever legal form the question is presented.

As a matter of actual experience, this question of custody is only presented for determination by the court in a small percentage of cases where divorce is granted. Most of the cases filed are uncontested divorce cases and raise no custody problem for the consideration of the court. One of the principal causes for this small number of uncontested cases arises from the fact that many men recognize that their children will be better cared for by the mother. Therefore, the father does not request custody in the divorce action. It is usually only the aggravated case involving the moral character of the wife, which results in a contest concerning the custody of the children. The amount of money to be allocated for the support of these children, in some instances, furnishes the reason and cause for a contested case. Judges are aware that this particular factor may be present in a contested case, and that inquiry should be made to establish the truth of this fact. It is necessary for the judge to try to determine the real reason behind the divorce action. Is the husband opposing the actions as a means to an end; or is he indirectly seeking other relief? The conclusion of the court as to the sincerity of the parties may have a direct bearing in the determination of the best interests of the child. This factor may sometimes be ascertained by inquiring of the husband the amount of support money which he believes he should pay. His answer usually reveals the purpose of the contest.

There is, therefore, a smaller number of cases involving this question of custody than the total amount of divorce litigation might suggest. It also follows that custody cases containing the reasoning of the judge are proportionately few in number. An opinion in these cases involves judicial discretion, and although judicial discretion is subject to review, the appellate court is only concerned with abuse of discretion by the trial court. The upper court recognizes that the presiding judge has had before him the parties, their children and the witnessses. He has had the opportunity of personal study of the parties. He also observes their conduct and demeanor. Being familiar with all surrounding circumstances, hearing the testimony, seeing the witnesses, interviewing the children, these are all matters which place the presiding judge in a better position to determine the best interests of the child.

Judges write decisions pertinent to legal questions, but do not readily expound concerning social problems. This character of appeal in divorce cases has influenced

${ }^{7}$ Keezer, The Law of Marriage and Divorce (1906) $\$ 588$. 
the procedure of the presiding judge in writing opinions. Few cases involving the custody of children are, therefore, appealed to the higher courts.

The minor child of the parties to a divorce action is a ward of the court. The court has power to change the custody of the child, to enforce the parental obligation, to provide maintenance, and if necessary to remove the child from the custody of both parents. No reservation in a decree of divorce is necessary for the court to continue its authority to make appropriate orders regarding the custody and maintenance of minor children of the marriage. Decrees for custody are generally regarded as temporary and are rarely made final. The court retains the power to change them for cause shown at any subsequent time. Where it once had jurisdiction of the parties and children, it may make a modification of its decree. ${ }^{8}$ This question of the award of custody may arise pending the action for divorce, after the divorce and on denial of divorce. The same factors to be considered are present in each case. Any requested change must be based upon different circumstances, or upon the wishes of the children. The controlling factors considered in an application for modification of a former decree are discussed in another portion of this symposium.

The continuing authority of the court to modify its decree at any time is a factor which judges use as an opportunity to try out certain arrangements concerning custody. This is done by a temporary order while the action for divorce is pending. The parties then report any resulting circumstances which either of the parents believe are not conducive to the best welfare of the child. Such an order amounts to trial custody. In actual practice the final decision for divorce is withheld during this period of time allocated for trial custody. By this procedure the court is in a better position to make a more intelligent decision, conditioned upon the actual experience concerning the welfare of the child or children during this trial period. The result of such an experiment can be incorporated in the final entry, which is placed on record as the decision of the original hearing. This procedure limits the case to one hearing. The parties are benefited by being limited to the expense of one trial.

\section{The Opportunities Open to the Trial Judge}

Custody is defined as "the control of a person with such actual or constructive possession as fulfills the purpose of the law or duty requiring it." Custody may be granted to one of the parents. Although the welfare of the child is the prime consideration, the legal right of the parent is an important factor to be respected. The civil English and American courts uniformly recognize and enforce this natural right of the parent. Neither the father nor mother possesses a.paramount right to custody. The court may grant custody to either parent or to a third person, providing both parents are unfit and the controlling circumstances require such action

${ }^{8}$ Emrich v. MfNeil, I26 F. (2d) 84 I (App. D. C. 1942); Annotation I46 A. L. R. II53 (1943); KEEZER, op. cit. supra note $7, \S 594$. 
for the welfare of the child. Courts follow the rule that the welfare of the child deserves greater consideration than the technical legal rights of the parent.

The custody of a child cannot, of course, be given to both of the parents at the same time. The court may direct continuous, divided or alternating custody between the separated parents. ${ }^{9}$ The procedure of dividing or alternating custody is often used when the two contesting parents are fit, and when the controlling circumstances are such that the court can readily protect the welfare of the child by granting custody to either parent. The factor to be remembered is the importance of due consideration for the child's schooling. It is in this class of cases that the judge usually grants the custody of the child to the mother during the school year and to the father during the vacation periods. All courts do not agree with reference to the advisability of this procedure. There are certain advantages and disadvantages. There are benefits to be derived from frequent associations with each divorced parent fit to have the child's custody. This alternating custody protects the future welfare of the child in the event that one of the parents should die. It also gives the child an opportunity to have the experience of two separate homes. This is material in the states where, at a certain age established by statute, the child has the right to prefer one parent over the other. ${ }^{10}$ The question of divided custody is not universally applied, because of the beliefs of the particular judge. Some judges consider that the child is entitled to the love, advice and training of both mother and father whenever possible. Other judges consider divided custody as undesirable. They reason that the right to visit the child at all reasonable times is sufficient. There certainly is a direct benefit to the future welfare of the child if that child has the advantage throughout the years of a mother and father. Fathers are apt to do more than the court entry calls for, in respect to maintenance and voluntary provisions for the education of their children, if they have been given the opportunity to exercise custody at some time over their children. Human nature never changes. Contact, good relationship and friendly feelings between parent and children are also conducive to the best interests of the child. This is the resulting factor which judges consider, but its application is a personal matter, depending upon the foresight of the judge, his backlog of experience, and his intense interest in the future as well as the present probTems of youth. The court is really only assuming proper responsibility in its decision for the future welfare of boys and girls who through no fault of their own have become wards of the court. There is no uniform approach to the problem. The factors in each case are different. The discretionary powers of the court involve a consideration of both legal and social problems.

Some cases present the question, because of the economic conditions involved, as to the separation of children where there is more than one child. The judge in exercising his discretion may find it necessary to separate the children. This practice

${ }^{2} 27$ C. J. S. $1169, \$ 308$ (d) (1941).

${ }^{10}$ Ohto Gen. Code Ann. (Page, 1938) \$8033. 
generally is avoided. Children should be kept together in the interests of the future of each family. ${ }^{11}$ This is one factor considered necessary for the protection of the children. It cannot be followed in all cases because of particular circumstances.

Some questions that confront the court with reference to custody of children can be solved by the use of adoption proceedings. Many cases are presented where the child has been in the actual custody of foster parents for several years prior to the time of the court hearing. The parents themselves wish the children to remain in the same environment which has existed for an extended period of time. There are many serious questions, however, which can later arise when one or the other of the parents seeks to secure an order changing the custody of the children. These future problems involving their welfare can be prevented if the court, at the time of the first hearing, suggests the use of adoption proceedings. This suggestion is only made when the court believes that the children as well as the parents will be benefited by the use of adoption proceedings, which permanently place the child or children in custody of the party who has satisfied the court as to eligibility. When parents advise the court that they wish their child to remain in the custody of a third person, it is usually their intention at that time that such custody should be permanent. The judge can settle this question forever by suggesting adoption. Usually such a settlement is for the best welfare of the child. If this is not done, the home of the child is insecure. Either party may change his mind, and a different judge, not knowing the facts, may be called upon to determine an application to change the custody of the child. The use of adoption proceedings has the effect of a final decree. It is an advisable procedure to be followed in a few instances. This determination of the custody of the children by the suggestion of adoption proceedings is not a legal matter, but legal procedure is used to accomplish such a social adjustment.

It is common to find the practice of adoption proceedings used when a modification of a court decree is requested because of the remarriage of one of the parents. After the remarriage of one of the parties, the stepparent seeks to adopt a child of the previous marriage. We again find the court presented with a decision involving the determination of legal rights. It may be for the best interests of the child to live with the parent who has remarried and for the judge to allow adoption proceedings. It is a serious question as to whether or not the other parent should legally be deprived of his locus parentis. When a child, by order of the court, is placed in the custody of one party, the child remains under the jurisdiction of the court. In most states the court may consent to an adoption proceeding. The court as parens patriae has the authority to act for either parent. Generally the trend is for the court to emphasize the legal rights of parents. It would appear that only in those cases where abandonment or desertion is present will the court ever consent to the stepfather or stepmother adopting a child of a previous marriage. ${ }^{12}$ In no

${ }^{21} 27$ C. J. S. I17o, $\$ 308$ (e) (I941).

${ }^{12}$ Hersey v. Hersey, 27 I Mass. 545, 7I N. E. 815 (1930), Annotation, 70 A. L. R. 518 at 526 (1931); Annotation, 24 A. L. R. 416 (1923). 
case where the father is carrying out the maintenance order established by the court should the court grant a request to take his child away from him by consenting to adoption proceedings. This request is often made when bitter feeling exists between the father and the mother. Courts must be thorough in their investigation of the particular facts. Legal rights are superior to any claimed advantages that might accrue to the child as a result of adoption proceedings. Consent of the father and mother should guide the court in permitting adoption to determine the future custody of the child.

The court is interested in the right of visitation afforded to the parent deprived of custody. ${ }^{13}$ The child should have the benefit of paternal and maternal influence. The parent who is not given custody has a right of visitation as a matter of course, and it is only forbidden in extreme cases. The usual divorce entry properly provides that the parent deprived of custody shall have the right to visit his children at stated times or periods, or at all reasonable times. The court, however, may withdraw this right of visitation where the visiting party becomes difficult or disagreeable. In such cases the court uses a different method of contact with the child. Many situations may have some bearing upon the final entry of custody. If the minor child happens to be outside of the state, opportunity for visitation may be limited. If extraordinary circumstances restrict the privilege, this factor may influence the court to order divided custody. There are other instances where the feeling between the two parents is so great that proper contact is impossible. A custodial parent often seeks to instill this bitter feeling in the mind of the child against the other parent by means of abusive and slanderous statements. Where such condition exists, most judges reason that it is preferable to grant custody at certain times instead of the opportunity to visit the child. The right of visitation must be protected.

\section{General Factors Affecting the Exercise of Judicial Discretion}

There are general factors which judges consider in determining to whom children are to be awarded in divorce actions. The interest and welfare of the child is the primary and controlling question by which the court must be guided. This rule is based upon the theory that the state must perpetuate itself, and good citizenship is essential to that end. ${ }^{14}$ The children of today are to be the men and women of tomorrow. While the state will not usurp the place or function of the parents, it has a special obligation to protect minors through our courts. Children are wards of the court. Their interest transcends all other claims and rights of the parents. The physical, moral and spiritual welfare of the child is the polar star by which the discretion of the court is to be guided. The maintenance of some normal family relationship is naturally favored. Ability to give proper parental attention is entitled to consideration as constituting a strong claim on behalf of the parents. They are preferred as guardians if they are fit for the trust.

${ }^{13}{ }_{7}$ Ax. Jor. 515, $\$ 679$ (1938).

${ }^{14}$ Moore v. Dozier, 128 Ga. 90, 57 S. E. I 10 (1907). 
Utter selfishness alone cannot be allowed to cut off the natural claim of parents to the custody of their own offspring. ${ }^{15}$ Human experience has demonstrated that children ordinarily will be best cared for by those who are bound to them by the ties of nature. Something more than the material things of life is essential to the nurture of a child, and that something is the father's and mother's love for their children. Recognizing this family relationship, the law raises a strong presumption that the child's welfare will be best subserved in the care and control of parents. Parental interest and rights make out a prima facie case for parents claiming the custody of their children. ${ }^{16}$ The love of the mother for her child regardless of conditions and environments can be counted upon most unfailingly. All the facts and circumstances in each case are different, and all pertinent aspects of family life receive the consideration of the court. So many elements enter into the decision concerning the best interests of the child, that it is difficult to formulate any general rule. Each case must be determined on its own merits and on its own peculiar facts. Experience teaches judges that they must possess the quality of human understanding in exercising this equitable jurisdiction. Even parental love must yield to the claims of another, if after judicial investigation it is found that the welfare of the child requires it. It is believed that judges are rarely influenced by any sentimental consideration in behalf of either the father or mother. The rights of either claimant do not take precedence over the rights of the child.

Another important factor influencing the court in its judgment is the desire of the child. In respect to the determination of the child's temporal, mental and moral welfare there is one paramount question. Is he of sufficient age to form an intelligent preference which the judge may take into consideration in determining proper custody? There is no fixed age when the discretion of the child begins. The proper test is mental capacity. Judges by consultation usually determine the interests and attitudes of the children, giving due cognizance to the fact that their welfare is superior to the rights and privileges of either of the parents. In deciding this question the court will take into consideration all facts that pertain to the interest of the children, the relative educational, social and moral advantages, the care and the love which the children may receive, the property of the parents and their financial situation. All these matters are considered in relation to the preference of the child. Welfare controls choice, and the court will not permit the choice of the child to lead to an improper custody.

Some state statutes regulate the age of discretion. ${ }^{17}$ In other states the age of discretion is a matter to be determined in each case, and this is usually done through private conferences. The court must be assured that neither parent is exerting any influence upon the judgment of the child. The wishes of the child are always considered, but they are not final. The judge must be certain that the child, in exercising preference, is free from all undue restraint. This privilege of choosing the

\footnotetext{
${ }^{16}$ Risting v. Sparboe, I79 Iowa II33, I62 N. W. 592 (1917).

16 Ibid.

${ }^{17}$ Orio Gen. Code Ans. (Page, I938) $\$ 8033$.
} 
desired parent, if the parent is a fit person, is considered along with all the other evidence presented. The judge is apt to be guided by this preference in direct proportion to the age of said child. Age, health, sex, perspective, home surroundings, associates, and opportunities of the child, together with the moral or immoral surroundings, and the pecuniary prospects, are all important factors in determining this perplexing question of custody. Courts hesitate to take from the mothers' arms young or delicate children unless it seems absolutely necessary for their best interests. ${ }^{18}$ The sex of the child may be a controlling factor. The age of the child is considered, whether it be determined by statute or by judicial discretion.

The wish of a child, of sufficient capacity to choose for himself, is a factor which is given special consideration when the parents have, over a long period of time, voluntarily allowed their child or children to live in the family of another. The court will make no coercive order in such cases to enforce the mere legal right of the parents to their custody in opposition to the manifest inclination and against the reasonable choice of the children. ${ }^{18}$ Some courts believe that it is a dangerous and perversive doctrine to hold that the mutual affections of the child and his temporary custodian should annul the natural right of the parent to his offispring. Here again it may be proper to repeat that each case must stand upon its own merits. Ordinarily a parent, by transplanting his offspring into another family and surrendering all care for such a length of time that the child's interests and affections attach themselves elsewhere, thereby seriously impairs his right to have said custody awarded by judicial decree.

Parents attempt to make their own agreements concerning custody. Such a contract may be considered, not for the purpose of fixing the rights of the parties, but to shed light upon their actual relations and feelings for the infant, and in assisting in the exercise of a sound discretion by the court as to what disposition should be made for the promotion of the best welfare of the child. ${ }^{20}$ The natural rights, claims and personal desires of parents should not be disregarded if they are not incompatible with that welfare. It is often necessary to determine the sincerity of an agreement. This sincerity may be revealed by questioning the interested parties concerning their sense of parental duty. A parent should not press his claim to custody whenever the true interests of such child forbid it. It is fortunate that the enlightened principles of our law authorize our courts to interpose in behalf of the child whenever parental obligations fail to influence sufficiently the conduct of either or both parents.

Most states treat these agreements which are made by parents for the transfer to others of the custody of their child or children, as being against public policy and, therefore, not enforceable or binding upon the parties. ${ }^{21}$ Courts, in any event, do not lightly and without good cause invade the natural right of the parent to the custody, care and control of his infant child. If the parent has made a contract with

\footnotetext{
${ }^{18}$ See Annotation, 4 I L. R. A. (N. S.) 565 at 575 ff. (1898).

${ }^{10}$ Church, Habeas Conpus (I884) $\$ 447$.

${ }^{20}$ Weir v. Marley, 99 Mo. 484, 12 S. W. 798 (I890); Tiffany, Domestic Rel.tinons (1896) 352.

${ }^{21}$ Hernandez v. Thomas, 50 Fla. 522, 39 So. 641 (I905).
} 
another person, surrendering to him the custody of the child, such contract may have much weight because it may show the unfitness of the parent and estop him from seeking to repudiate a fair and beneficial agreement. These contracts will not be incorporated as binding the parties, unless they are in the best interests of the child. ${ }^{22}$

The opinions of the courts differ, some courts holding such a contract void as against public policy, but others treating them as presumptively valid.23 Most, if not all, of the decisions can be reconciled by applying this test: Is the contract in question favorable or unfavorable to the advantage of the child? Applying this test, it would appear not illegal for parents who have separated to enter into a contract with each other for the custody and maintenance of their children. If the contract is one which the court would approve, keeping the welfare of the child paramount, it may recognize such contract. This agreement will not be enforced by the court longer than circumstances prove it beneficial to the child. Parents entering into their own arrangements are presumed to do so in contemplation of their obligations under the law and with respect to the rights of the child. ${ }^{24}$

\section{Spechal FACTORS}

Some mention should be made of special factors which judges consider in determining custody of children and these special factors pertain to the conduct of each of the parents. When the parent who seeks the custody of the child is guilty of immoral conduct, the general rule is that the custody of the child will be denied to such parent. ${ }^{25}$ It is in these cases that courts experience, realistically, that family troubles are essentially social problems and not legal problems. It would seem to be improper to grant custody of a child to a dissipated or immoral mother with the expressed hope that this action might tend to the reformation of the mother's actions. A mere promise to reform should not be sufficient to grant custody to an improper person. ${ }^{26}$ Who should be given custody of the child-the mother who has been divorced for adultery and will take good care of the child, or the devoted father who is at work and away from home most of the day?

Cruelty, ${ }^{27}$ immorality, habitual drunkenness, ${ }^{28}$ failure of father to support, failure of mother properly to care for her child or children, and general incompetence of a parent are usually held sufficient cause to deny such parent the custody of the child. If a father or one standing in loco parentis is a drunkard, or a criminal, or is cruel, or shiftless, or otherwise unfit, the interests of the child completely outweigh his

${ }^{22}{ }^{4}$ R. C. L. $271, \$ 44$ (1920); KEEZER, op. cit., supra note 8 , $\$ 591$. (1920).

${ }^{23}$ Annotation, 4I L. R. A. (N. S.) 565 at $57^{8}$ (1913); cases collected in 14 R. C. L. 273 , note 6

${ }^{24}$ Sce Edleson v. Edleson, $179 \mathrm{Ky} .300,200$ S. W. 625, 63I (I9I8).

${ }^{25}$ See Annotation, 4I L. R. A. (N. S.) 565 at 603 (I913).

${ }^{20}$ In re Lee, 165 Cal. 279, 131 Pac. 749 (1913); In re Lally, 85 lowa 49, 51 N. W. 1155 (1892).

${ }^{27}$ See Annotation, 4I L. R. A. (N. S.) 565 at 591 (1913) and cases cited therein.

${ }^{28}$ What is habitual drunkenness? Too many cases attempt to proceed with this ground for divorce against the husband. One question proposed by the court usually reveals that the husband is a steady worker. 
parental right of custody. ${ }^{29}$ In the determination of what constitutes cruelty, regard must be had to the physical and mental condition of the parties and to their character and social position. ${ }^{30}$ Acts of cruelty must be corroborated, substantial and not provoked by the complaining party. Other factors to be considered include age, temperament, parental interest and the disposition of the two spouses. As a general rule, a single act of violence is not cruelty sufficient to eliminate all other factors to be ordinarily considered in determining custody of children. ${ }^{31}$

Abandonment or desertion by the parent is generally held good cause to deny the custody of the child to such parent. ${ }^{32}$ Oftentimes in such instances the parent claims he has not relinquished his right of custody, care and control of the infant, but that he has made an agreement with a third party to take care of the child for a certain period of time and for a certain sum of money, until the claimant can provide a satisfactory home. ${ }^{33}$

While criminality of a parent is persuasive evidence of unfitness, the violation of a criminal law would not be conclusive of moral turpitude.

In this country the full and free right to entertain any religious belief, to practice any religious rites or ceremonies and to teach any religious doctrines, which do not violate the laws of morality and property and which do not infringe upon personal rights, is conceded to all. ${ }^{34}$ It is to be doubted whether any American court would remove infants from the custody of a parent because his or her principles and teachings were irreligious, skeptical or even atheistical, unless they were positively immoral. ${ }^{35}$ The results of religious fanaticism, however, may interfere with the child's normal development to such an extent that they may be of considerable weight in determining the award of custody. ${ }^{36}$ Generally the courts have no authority over that part of a child's training which pertains to religious principles. In a dispute relating to custody, religious views afford no ground for depriving a parent of custody who is otherwise qualified. ${ }^{37}$ Modern authority follows the principle that the right of custody includes the privilege of dictating the religious teachings which the child shall receive. ${ }^{38}$ This seems true, even though there was a prior agreement between the father and mother pertaining to the religious education of the child. ${ }^{80}$ Such contracts are not enforceable at law or in equity. ${ }^{40}$ The court will keep in

${ }^{20}$ Marshall v. Reams, 32 Fla. 499, I4 So. 95 (I893); In re Gustow, 220 N. Y. 373, I15 N. E. 995 (r917); Chapsky v. Wood, 26 Kan. 650 (188r); In re Brown, II7 Ill. App. 332 (Ig04); TirpanY, Domestic ReLATions (I8g6) 346.

${ }^{30}$ Day v. Day, 5 Alaska 584 (1938). $\quad{ }^{31}$ Werres v. Werres, 102 Ill. App. 360 (1902).

${ }^{32}$ Annotation, 4I L. R. A. (N. S.) 564 at 594 (I913).

${ }^{33}$ State ex rel. Palmer v. Postlethwaite, ro6 W. Va. 383 , 145 S. E. 738 (1928).

${ }^{34}$ See Watson v. Jones, 13 Wall. 679 at 733,20 L. Ed. 666 at 679 (U. S. I87x).

${ }^{35}$ Sé (1936) 49 Harv. L. Rev. 831 (recent case discussion).

${ }^{30}$ People ex rel. Sisson v. Sisson, 246 App. Div. 151, 28I N. Y. Supp. 559 (1935).

${ }^{37}$ Jones v. Bowman, 13 Wyo. 79, 77 Pac. 439 (1904); Purinton v. Jemrock, 195 Mass. 187, 80

N. E. 802 (1907); Hernandez v. Thomas, 50 Fla. 522, 39 So. 641 (1905).

${ }^{38}$ Friedman, Religious Education of a Child (I916) 29 Harv. L. Rev. 485.

${ }^{30}$ Denton v. James, 107 Kan. 729, 993 Pac. 307 (1922); Annotation, 12 A. L. R. 1153 (1922).

10 Ibid.; Brewer v. Cary, 148 Mo. App. 193, 127 S. W. 685 (1910). 
mind the factor that a controversial religious question is not to be considered in awarding custody of the child. ${ }^{41}$ The question of religion of the child is settled when the right of custody is determined. The judge obviously must not allow his discretion to be guided by his own particular religious views.

It goes without saying that the judge is not influenced because of his own political views. There is no relation between the parent's political creed and the child's welfare to justify an inquiry into the former's belief. Communistic or atheistic views ordinarily are not factors influencing the court in its determination of custody. ${ }^{42}$ Pro-German sympathy and disloyalty to the American flag has been held not to warrant an order denying the father all access to his minor son. ${ }^{43}$

The question always to be determined concerns the fitness of the parents. If the mother is morally unfit to raise the child, then custody should be withheld from her and given to the father, unless he is disqualified for the same reason. The father should be given the custody in cases where he is the proper person, and the mother is shown to be of unchaste character. This is also true when she would rear the child in immoral surroundings; or when the mother voluntarily has parted with the child and the father has continued to keep it; or when the mother's treatment of the child has been such as to endanger its health. The fact that the conduct of the mother is not what others might think proper is not sufficient in itself to deprive her of the right to the permanent or periodic custody of her minor child. The question the court must determine is whether or not the mother is an unfit and improper person to be entrusted with custody, care and control, which might endanger the welfare of the child.

The factor of the financial condition of the parents must also be considered. A well-to-do parent is not entitled to the child because of that fact. It is true that the general economic condition of the separated family is an important consideration in all these cases, and that the amount of maintenance directly affects the future welfare of the child. Ordinarily, the amount of maintenance granted is not large enough to properly support the mother and children. She must seek employment or live with relatives. An award made in a divorce case is conclusive only as regards the facts at the time the decree is made, and only as it applies to the parties thereto. The right of the court to change custody or maintenance orders at future dates is a protection for the children.

The sincerity of the parents is a factor which judges consider. Their actions and their testimony in court are often indicative of this and of their individual interest in the child. In some cases it is necessary to determine why the father is seeking custody. Is it for the purpose of giving the child a better home? Perhaps it is merely an argument for his own protection, to prevent his paying what he

\footnotetext{
"1 Members of the Jehovah's Witnesses sect may prove to be the exception to this rule. One wonders whether courts may take the view, articulately or not, that mothers seem susceptible to this sect, formerly called Russellites, and in many instances spend their time preaching on street corners instead of taking proper care of their homes and children.

"supra note 35.

${ }^{43}$ Kennard v. Kennard, 87 N. H. 320 , I79 Atl. 414 (1935).
} 
may feel is an excessive amount of alimony for the support of his children in some other home.

The character of each of the parties is vital in all questions concerning custody. This is especially true when the party at fault is seeking custody. The other parent is usually favored for the care of the children. The fact that a party has some faults of character will not prevent custody being awarded to such party. It is important in the trial on this issue that evidence touching the character, conduct and reputation of either of the parties, or any other evidence tending to throw light on his or her fitness, is admissible. Conclusions, deducible from this testimony, are not the subject matter of opinion by the witness. The unfitness which deprives a parent of his natural right to the custody of his children must be positive and not comparative. The degree thereof must be considered in relation to all circumstances, such as: the concern that has been shown in the past; the suitability of domestic surroundings to receive the children; and the question of their general welfare. Inquiry extends not only into the ability of the parent properly to maintain and care for the child, but also into the habits and character of the parties.

In determining the weight and credit to be given to the testimony of the witnesses, judges consider their intelligence and their manner and conduct on the witness stand. Furthermore, consideration must be given to any reluctance on the part of any witness in testifying, and to the zeal or feeling exhibited for or against either side. The judge also studies the relation which each witness bears to the parties in the suit, his interest, if any, in the result and the motives that might cause the witness to swear falsely. The rules governing the construction and effect of circumstantial evidence must be considered. Corroborating evidence is always necessary in domestic relations cases. Greater weight and probative effect is usually placed upon the admissions of a party. Judges recognize the fact that the parties are the most interested persons in the controversy. Those who testify are usually partial in their opinions. Disinterested witnesses are not the general rule in a divorce case. This factor requires the judge to be cautious. It is not difficult for a witness to exaggerate or misinterpret an incident. A playful act or friendly but indiscreet behavior may be embellished as a wrongful act. Too much testimony in many domestic relations cases would seem to be tainted with the crime of perjury. Judges know this human factor connected with the presentation of this type of testimony. They try to sift the entire evidence to establish the true facts. This is an interesting and important function that requires serious thought. It is not a matter of mathematical computation. The conclusion may be the controlling social factor upon which rests the future welfare of the minor children of the parties.

\section{Conclusion}

Summarizing, the general and special factors which judges consider in awarding custody of children may be briefly set forth as follows: welfare of child; fitness of parents; preference of child; his age, health and sex; residence, surroundings and 
opportunities; desires of parents and agreements between them; character and reputation of parties as well as their financial condition, sincerity or fault; opportunity for visitations; results of private conferences with the judge; credibility of the witnesses; natural right of parents and any trial custody; possible use of adoption proceedings and potentiality of maintaining natural family relations; age of discretion and opportunities affecting the future life of said child. Judges must also be guided by the separate grounds for divorce ${ }^{44}$ that now exist by statutes in fortyseven of our states. ${ }^{45}$ These factors are significantly associated with the discretion exercised in determining the custody of children. There naturally would be a divergence of opinion as to the relative importance of each factor and no attempt has been made to list them in the order of their importance. The weight of these independent factors may vary according to the approach of the judge and the tenor of the laws of each state. The scope of this article does not permit an exhaustive presentation of the entire subject matter.

Social factors usually outweigh legal factors, when one analyzes the responsibility of judges today in deciding these challenging custody problems. Judges need the assistance of additional professional personnel. Case history data may be important, and may reveal the process of disintegration of the family. Some states provide by statute that the report of a juvenile officer, or some person appointed by the court, is to be considered part of the record in determining custody of children. ${ }^{46}$ This investigation into the character, reputation, home surroundings, case history and habits of each parent is important in the consideration of the social problems involved. ${ }^{47}$ Courts may make their own investigations. Ordinarily, there are no social workers or facilities at their disposal. The temper of the times is unquestionably favorable to emphasizing the sociological aspects in domestic relations cases. Members of the bench and bar must guide the application of this trend.

\footnotetext{
"Statutes generally include one or more of the following grounds for divorce: willful absence of either party from the other for three years; that either party had a husband or wife living at the time of the marriage from which the divorce is sought; adultery; impotency; extreme cruelty; fraudulent contract; gross neglect of duty; habitual drunkenness; the imprisonmnet of either party in a penitentiary under sentence thereto; incurable insanity.

We also find statutes pertaining to the following grounds for divorce: in favor of either party when the other was at the time of the marriage physically and incurably incapacitated from entering into the marriage state; the procurement of a divorce without the state by a husband or wife; the commission of a crime against nature, whether with mankind or beast, either before or after marriage; when prior to the marriage either party shall have been convicted of a felony or infamous crime in any state, territory or country without the knowledge on the part of the other party of such fact at the time of such marriage (Arizona); pregnancy of the wife at the time of the marriage unknown to the husband (Arizona and Georgia); seven years' absence during all which period the absent party has not been heard from (Connecticut); concealment from the other party of any loathsome disease existing at the time of the marriage or contracting such afterwards (Kentucky); uniting with any religious society whose creed and rules require a renunciation of the marriage covenant or forbid husband and wife in cohabiting (Kentucky); a public defamation on the part of one of the married persons toward the other (Louisiana); an attempt of one of the married persons against the life of the other (Louisiana); habitual and excessive use of opium, morphine or other like drug (Mississippi); when the husband shall be guilty of such conduct as to constitute him a vagrant within the meaning of the law respecting vagrants.

"There are no divorce statutes in the state of South Carolina.

${ }^{4}$ E.g., Ohio Gen. Code AnN. (Page 1938) \$rig79.

${ }^{47}$ Williams v. Gwynes, 97 S. W. (2d) 988 (Tex. Civ. App. 1936).
} 
Lawyers are officers of the court. It is to be presumed that they make thorough examinations concerning the facts in their cases. When requested by the court, their opinions relative to proper custody are helpful. In private conferences, after all the evidence is presented, lawyers, as officers of the court, are more than willing to aid the court in arriving at a proper solution of this public problem. Attorneys are interested in the welfare of children, and when called upon by the judge for information they are honest and fair in their recommendations. The suggestion of the lawyer is a factor which judges consider in determining award of custody of children.

Judges and lawyers are finally assuming their proper responsibility for true, just and equitable decisions which protect the welfare of the youth of our broken homes, who themselves may have the responsibility of parentage tomorrow. 